\title{
ОСОБЛИВОСТІ МАНІПУЛЯТИВНОГО МОВНОГО ВПЛИВУ У ВІЙСЬКОВИХ І ПРАВООХОРОННИХ ПЕРІОДИЧНИХ ВИДАННЯХ УКРАЇНИ
}

Посмітна В. В. Особливості маніпулятивного мовного впливу у військових i правоохоронних періодичних виданнях України.

У статті обгрунтовано специфіку маніпулятивного мовного впливу в дискурсі вітчизняних військових і правоохоронних друкованих видань. Виявлено основні цілі застосування маніпуляцій в аналізованій галузевій періодиці, визначено мовні та дискурсивні засоби маніпулятивного впливу, встановлено його недеструктивний характер.

Ключові слова: маніпулятивний мовний вплив, комунікативні цілі, засоби мовного впливу, деструктивний і недеструктивний вплив.

Посмитная В. В. Особенности манипулятивного речевого воздействия в военных и правоохранительных периодических изданиях Украины.

В статье обоснована специфика манипулятивного речевого воздействия в дискурсе отечественных военных и правоохранительных печатних изданий. Выявлены основные цели использования манипуляций в анализируемой отраслевой периодике, определены языковые и дискурсивные средства манипулятивного воздействия, установлен его недеструктивный характер.

Ключевые слова: манипулятивное речевое воздействие, коммуникативные цели, средства речевого воздействия, деструктивное и недеструктивное воздействие.

Posmitna V. V. Features of manipulative speech influence in the Ukrainian military and law-enforcement periodicals.

The article identifies the specificity of manipulative speech influence in the discourse of national military and law-enforcement printed editions. The main purposes of manipulation in the examined branch periodicals are pointed out, language and discourse means of manipulative influence are identified, its non-destructive nature is determined.

Key words: manipulative speech influence, communicative purposes, means of speech influence, destructive and non-destructive influence.

Маніпулювання масовою свідомістю - одна 3 найбільш гострих проблем сьогодення. Сучасна людина живе в мегаінформаційному просторі і не може уникнути впливу засобів масової комунікації. У цьому контексті надзвичайно важливим $\epsilon$ питання про відповідність чи невідповідність здійснюваного впливу моральним нормам суспільства, загальнолюдським цінностям. 
Пошук шляхів розв'язання проблем маніпулятивного мовного впливу зумовлює полеміку серед представників різних наукових напрямів $[6 ; 8 ; 9 ; 10 ; 11 ; 12 ; 14$ та ін.]. Науковці досліджують його природу, виявляють основні характеристики, визначають засоби, аналізують цілі та прогнозують наслідки застосування $[3 ; 5 ; 9 ; 10 ; 11]$. Маніпулювання $є$ одним із основних аспектів дослідження масмедійного дискурсу $[1 ; 2 ; 4 ; 7 ; 9 ; 10 ; 11 ; 13]$.

Питання про особливості маніпулятивного мовного впливу у вітчизняних військових і правоохоронних друкованих виданнях не було об'єктом спеціального дослідження, хоча це питання набуває сьогодні все більшої актуальності. Маніпулювання в публіцистичних текстах військової та правоохоронної сфер може стати особливо небезпечним - як для окремої особи, так і для суспільства загалом. Специфічна тематика вимагає чіткого визначення цілей застосування маніпулятивного впливу та обережності у використанні мовних засобів, оскільки від цього залежить зорієнтованість громадської думки або на спокій у країні і мирне співіснування, або на ворожнечу і розпалювання війни.

Завдання цього дослідження - виявити цілі застосування маніпуляцій, встановити специфіку маніпулятивних прийомів, визначити основні засоби маніпулювання, з'ясувати характер маніпулятивного мовного впливу у військових та правоохоронних періодичних виданнях.

Ураховуючи зміст різних дефініцій маніпулятивного впливу [3; 5; 6; 11 та ін.], тлумачимо його як прихований вид мовно-психологічного впливу, спрямований на збудження в реципієнта намірів, що відповідають комунікативним інтенціям суб'єкта впливу. За основний критерій виділення маніпулятивного впливу приймаємо його прихований характер, неусвідомлюваність адресатом [11, с. 31]. Вважаємо, що саме прихований характер визначає такі особливості маніпулювання, як усвідомлюваність суб'єктом [там само] та здійснення поза волею об'єкта [11, с. 151].

Розглянемо маніпулятивний мовний вплив у військовій періодиці на матеріалі журналів «Військо України» та «Слово честі». На перших сторінках щомісячного журналу «Військо України» друкуються повідомлення про основні заходи керівництва держави, що стосуються силових структур, 3 обов'язковими посиланнями на висловлення 
Президента України та Міністра оборони України. В одному з номерів названого журналу (№ 6, 2011 р.) розміщені три повідомлення із заголовками-цитатами 3 виступів вищого керівництва. Повідомлення пов'язані за структурою та змістом: Президент України окреслює проблему (Корупчія $\epsilon$ загрозою національній безпеці України) - у Міністерстві оборони України одразу ж уживають конкретних заходів щодо іiі вирішення (Внутрішній аудит, щзо впроваджується 6 Міністерстві оборони України з наступного року, $\epsilon$ сучасним випробуваним інструментом запобігання та протидї корупиіï) - усе це відбувається паралельно 3 іншими реформами, які ще раніше визначив Міністр оборони України i які відповідають загальному напряму розвитку національної безпеки України (До 2016 року Україна повинна мати Збройні Сили нового зразка, і ніхто, крім нас, це завдання не виконає). Отже, на тлі відкритого інформативного мовного впливу (які напрями діяльності визначає нам керівництво) здійснюється і прихований - формується позитивна оцінка послідовних і злагоджених дій керівництва, навіюється думка про необхідність реформ у військах, а також про важливість узгоджувати власні кроки з керівними настановами і швидко реагувати на рішення вищих посадових осіб.

Iз власне мовних засобів, що сприяють реалізації прихованого впливу, слід виділити регулярне підкреслення посадових регалій (Президент України - Верховний Головнокомандувач Збройних Сил Украйни Віктор Янукович; начальник Генерального штабу Головнокомандувач Збройних Сил Украӥни генерал-полковник Григорій Педченко); регулярне цитування висловлень керівництва в текстах повідомлень; уживання оцінної лексики, слів у переносному значенні («корупційний податок» $\epsilon$ важким тягарем; масштабна тінізація економіки; корупція є гальмом модернізації; реформування - процес болючий); стильовий контраст наведеної експресивно забарвленої лексики i стандартних офіційно-ділових конструкцій (заходи 3 оптимізації структурних підрозділів; усунення виявлених недоліків; питання щзодо підготовки запровадження; завдання підготовки внутрішніх аудиторів); використання інклюзивної функції займенників (ми з вами повинні запропонувати способи боротьби; ніхто, крім нас, це завдання не виконає).

Реалізуванню прихованих ілокутивних намірів сприяють i невербальні, дискурсивні, засоби мовного впливу (обрамлення червоним кольором; виділення жирним шрифтом цитатних заголовків; 
розмір шрифту цитати тим більший, чим вища посада мовця; контекстуальна узгодженість змісту заголовків; принцип розміщення фотографій - знімок Міністра оборони України поруч зі знімком Президента України, але дещо нижче).

В іншому номері журналу «Військо України» надрукована стаття «Фарватер миру - 2011»: братерство по-флотськи, типова для цього видання розповідь про проведення військових навчань. На перший погляд, мета авторів - проінформувати читача про чергові військові навчання, детально ознайомити 3 найбільш цікавими моментами та результатами. Проте значна кількість засобів вказує на те, що інформування підпорядковане іншим, прихованим, але більш важливим завданням:

- сформувати високу оцінку рівня боєздатності армії та підготовки українських військовослужбовців: вживання (i повторення) слів 3 оцінним значенням (успішно; спроможність; нищівний удар; злагоджено; повітряні аси; иүілковите накриття цілі; пряме влучення; морська піхота виявила свої найкращі якості: мобільність, швидкість, рішучість, здатність виконати бойове завдання понад усе), характеристика озброєння та техніки, а також описування їх можливостей (мінні тральщики; двоорудійні артустановки АK-725; вертоліт Ка-27; великий десантний корабель маневрував, успішно боровся з морськими мінами та здійснив низку бойових стрільб);

- сформувати позитивну оцінку співпраці 3 російськими військовими: сьогодні важливо разом протидіяти таким колективним загрозам, як піратство $i$ тероризм; в умовах повної довіри, взаємовиручки та порозуміння; злагодженість та зміцнення взаємодї; регулярне вживання слів дружній, взаємодія, спільно, співробітництво, об'єднаний; конструкції 3 оцінним значенням: справжне свято військової доблесті й звитяги;

- переконати в миротворчому характері діяльності військових: уже в заголовку вжито слова мир і братерство; у самому тексті задля цього використовуються вислови: миротворчі операщї; створили зони безпеки для цчивільного населення; ліквідували незаконні збройні формування; створення безпечної економічної діяльності й захисту судноплавства;

- навіяти думку про те, що безпека потребує вкладання коштів в армію: підкреслення масштабності заходу (міжнародний захід; насичення 
й інтенсивність навчань; баталія; виконання цілого комплексу завдань на морі, у повітрі та на суші); наведення конкретних цифрових даних (y навчанні взяли участь 9 бойових кораблів, 10 літальних апаратів, 64 одиниці автобронетанкової і спеціальної техніки); наведення думки про залежність боєздатності від технічного забезпечення зі слів самих учасників заходу (Запорукою високого результату стали належна технічна готовність та справність озброєння і військової техніки. Я був упевнений у наших силах).

Досягненню прихованих цілей сприяє зацікавленість, на формування якої спрямовані такі мовні засоби: слова 3 емоційним забарвленням (кинулись у двобій; спортивний запал; приголомиливий), розмовна лексика (дали фору; наші хлопиі), асоціативний ефект заголовка та підзаголовків (по-флотськи; морський бій), слова в переносному значенні («воював»; «міни»; «збірна»; «супротивник»; родзинка; діі «чорних беретів»); стильовий контраст (хитромудра комбінаџія; пальма першості у стовідсотковій укомплектованості) та ефект несподіванки (один із розділів названий «Фарватер миру» розпочинається 3 ... футзалу). Із дискурсивних засобів слід назвати: 1) велику кількість яскравих фотографій, що відразу привертають увагу, вони займають площу практично таку саму, як і текст, переважна більшість із них розміщена на перших двох сторінках, навіть текст цих сторінок надрукований на тлі фотознімка; 2) структурну особливість: одразу після вступної частини, що містить стислу характеристику події, надрукований розділ про футбольний матч між учасниками навчань, представлений як емоційна дружня розповідь. Реалізації названих прихованих цілей сприяє ix узгодженість із когнітивними уявленнями українських читачів (позитивна конотація концепту захисник в етнічній картині світу; сила та почуття обов'язку як необхідні компоненти змісту концепту).

На досягнення виявлених цілей спрямовані й маніпулятивні прийоми в текстах часопису внутрішніх військ МВС України «Слово честі» (військове видання, пов'язане також із правоохоронною сферою, оскільки висвітлює діяльність військових правоохоронців). Навіюванню позитивної оцінки слугують урочисті висловлювання, піднесений стиль, слова 3 позитивним оцінним значенням: Нові випробування - нові перемоги; Сила - у злагодженості; Внутрішні війська продовжують успішно розвиватися, стають загартованішими та міцнішими; Наш внесок у боротьбу 3 наркобізнесом; На варті безпеки ЧАЕС. Висловлюється також 
упевненість у тому, що труднощі нас не лякають, ми вміємо їх долати: «У державі є військове формування, яке попри всі негаразди виконує покладені на нього завдання, має мічний бойовий дух», - зазначив командувач; Начальник Навчального иентру внутрішніх військ МВС України полковник Олександр Рачок: «Головне, щзо у нас є потенціал $i$ бажання працюювати».

Проблеми не замовчуються, але вони подаються як такі, що вже вирішуються. Саме наявністю проблем пояснюється необхідність реформування. Приклад зі статті про підведення підсумків службовобойової діяльності внутрішніх військ: Занепокоєння командування внутрішніх військ МВС України викликає ситуація з підготовкою молодших командирів та фахівців. Вимагає покращення система відбору та проведення занять із особовим складом у Навчальному иентрі внутрішніх військ. Командувач наказав відповідним посадовим особам до вересня підготувати Положення про Навчальний центр та опраџюювати нові методики ци програми навчання різних категорій військовослужбовців. Інший приклад: Не можна не відзначити негативну тендениію масового відтоку офіцерів батальйонної ланки. 3 а шість місяиів поточного року з лав внутрішніх військ звільнився 151 офічер, щуо вдвічі більще, ніж за аналогічний період минулого року... Удосконалення системи військового управління вже почалося.

Отже, основними цілями застосування маніпулятивного впливу в дискурсі аналізованих військових видань є: 1) формування думки про достатній рівень обороноздатності армії та про правильність здійснюваних керівництвом кроків (у нас усе йде так, як і має бути); 2) навіювання думки про необхідність реформ (це змінить наше життя на краще, ми всі повинні працювати в одному напрямі).

Визначимо цілі та засоби застосування маніпулятивного мовного впливу у друкованих виданнях, пов'язаних із діяльністю правоохоронних органів, на матеріалі газет «Іменем закону» та «Криминальная хроника».

Періодичні видання МВС підтримують лінію держави та уряду, тому загальна мета здійснення ними маніпулятивного впливу викликати схвалення державної політики та бажання іiі підтримувати, сформувати позитивну оцінку урядових заходів (особливо ініційованих MBC) i дій правоохоронців, сформувати відчуття захищеності, впевненості в майбутньому. Аналіз дозволяє стверджувати, що 
налаштування на позитивний лад є однією з основних маніпулятивних цілей періодики МВС.

Періодичні видання правоохоронних органів сприяють запобіганню злочинності, тому негативне ставлення в читача повинні викликати всі, без винятку, порушення закону і права (навіть незначні, навіть власні), а також самі правопорушники (без поділу на «своїх» i «чужих», «благородних» i «неблагородних», i3 запереченням поняття «благородний злочинець»). При цьому зазвичай дискредитується попереднє керівництво та уряд, досить часто саме діяльністю колишніх керівників пояснюється високий рівень злочинності, велика кількість правопорушень та ДТП тощо.

Інколи проблеми державного рівня примушують представників влади приймати так звані «непопулярні» рішення, ініціювати заходи, що дадуть результати в майбутньому, сьогодні ж вони можуть сприйматися громадянами тільки як порушення усталеного, звичного способу життя. Підготувати громадян до позитивного сприйняття цих змін, дати час осмислити їх значення та необхідність - ще одне маніпулятивне завдання правоохоронних видань. Проаналізуємо втілення маніпулятивних цілей на конкретних прикладах.

У двох номерах газети «Іменем закону» (№ 1 та № 3 за 2008 р.) надруковані статті, присвячені заходам посилення безпеки дорожнього руху. Усі дискурсивні та мовні засоби в цих статтях спрямовані на переконання читача в необхідності нових рішучих заходів для вирішення проблеми правопорушень на дорогах, а також у правильності та прогресивності підходів нового керівництва. Уже в заголовку статті Невигаданий екстрім, або Автоиляхи як фактор демографічної кризи підкреслюється масштабність проблеми. Назва рубрики Злободенний момент вказує на актуальність порушеного у статті питання. Структурування тексту вважається одним із основних маніпулятивних прийомів [2, с. 148]. Стаття складається 3 4-х розділів: перший має назву Поблажливість до добра не довела і демонструє неефективність заходів попереднього керівництва; у другому розділі, Бешкетливі україниі, детально, 3 наведенням цифрових даних, характеризується рівень ДТП, звертається увага на кількість загиблих; у третьому розділі під назвою $A$ все ж, чого нам не вистачає? автори намагаються виявити причини правопорушень на дорогах $\mathrm{i}$ планомірно підводять читача до думки, що всі колишні засоби боротьби не здатні покращити становище; нарешті, у четвертому 
розділі, Без компромісів, вказуються ті нові рішучі заходи, які й вирішать проблеми, а щоб читач переконався в ефективності цих засобів, наводяться позитивні результати, що вже дали про себе знати.

Графічне і кольорове виділення окремих цифрових повідомлень та заголовка (білим кольором на червоному або на чорному фоні), різнокольорові графіки свідчать про застосування такого відомого методу впливу, як виділення окремих фрагментів. Сама стаття, розміщена на чорному фоні, виділяється 3-поміж інших - таким чином привертається увага. Символіка кольору застосовується також для психологічного впливу - формування почуття тривоги і неспокою: такі негативні стани, як відомо, людина прагне подолати, а тому наведені в тексті заходи сприймає як вихід, отже, позитивно.

Як метод мовного впливу у статті використовується й аргументований коментар подій [1, с. 19], зокрема такі прийоми цього методу, як 1) постійні посилання на факти та 2) посилання на авторитети. Посилання на факти (одразу привертають увагу чотири графіки з інформацією про кількість ДТП та потерпілих, три графічно виділені цифрові повідомлення такого самого характеру, у самому тексті декілька разів наводяться цифрові дані) формують враження дійсно жахливої ситуації на українських дорогах. Посилання на авторитетну думку начальника ДДАІ про результативність нових засобів боротьби 3 правопорушниками також використовується як аргумент у доведенні необхідності цих заходів.

3 інших маніпулятивних прийомів найбільш виразними є такі: 1) повторення слів потерпілий, аварійний в оцінюванні минулорічної ситуації, та покращення, новий, зміни, коли йдеться про сьогодення; крім того, читача неодноразово запевняють у тому, що ситуащія трунтовно вивчена, сьогодні під постійним контролем; 2) надання матеріалу в надмірній кількості - перенасичення цифровою інформацією, що заважає об'єктивно оцінити ситуацію; 3) велика кількість порівнянь: порівнюється рівень аварійності в Україні у 2007 році та за 15 днів 2008 року, рівень смертності внаслідок ДТП в Україні і в інших країнах Свропи тощо, порівняння доповнені висновками про складність ситуації (обігнали всю Європу) та іiі погіршення - усе це спрямовано на формування в читача думки про необхідність нових, рішучих заходів; 4) маніпулювання поняттями: методи боротьби колишнього керівництва іронічно названі 
лібералізащією, стан на дорогах унаслідок таких дій - екстрімом; при цьому яскраво виражене спрощення понять: протиставлення минулесучасне має «чорно-білий» характер [2, с. 147].

Негативна оцінка ситуації на автошляхах та позитивне сприйняття нових заходів формується значною мірою за допомогою таких мовних засобів: підсилення заперечення (аж ніяк не сприяють), гіперболізація (гіпераварійна ситуаџія; зростання аварійності набуло галопуючого темпу; ситуація кардинально покращилась), іронія («вагомий» внесок у погіршення; така «дрібниця», як справність технічного засобу), стильовий контраст (кепська демографічна ситуачія; ДТП скоюється «під шафе»; позитивний результат не забарився), оцінні сталі сполуки (з хворої голови на здорову; рубали з плеча; розводимо руками) та ін.

Подібні засоби досягнення тієї самої мети використовуються також у статті Що може ДАІ без «кумівства»? Композиція тексту інша, але так само «виграшна». Текст умовно можна поділити на три частини, що відображають причинно-наслідкові зв'язки: 1) жахливий рівень ДТП минулого року (за словами Міністра внутрішніх справ) - i низка заходів щодо «покращення, підвищення...»; 2) знову слова Міністра внутрішніх справ, його враження як водія - і оцінка нових заходів; 3) і втретє чергується пояснення необхідності змін (слова начальника ДДАІ) - i перерахування конкретних заходів щодо покращення. Як бачимо, яскраво виражений також прийом посилання на авторитети. Крім того, використовуються прийоми: маніпулювання поняттями, зокрема навішування ярликів (кумівство; свати-куми); повторення (мобільні групи швидкого реагування; оперативні мобільні групи); підсилення заперечення (виконували неналежним чином $і$ не в повному обсязі; на жаль, не сповна використовували); маніпулювання спрощеними поняттями, підсилене експресивно-емотивними метафорами, у яких оцінка «гарно / погано» пов'язана 3 поняттями «верх / низ» (раніше - низька щзільність нарядів ДПС; сьогодні підвищено щзільність).

Через півроку, перед упровадженням нових засобів боротьби 3 порушниками правил дорожнього руху, у газеті «Іменем закону» знову з'являються статті, присвячені цій темі. У них використовуються як основні такі самі методи мовного впливу аргументований коментар подій, посилання на факти, посилання на авторитети. Залишаються також основні маніпулятивні прийоми: 
1) структурування тексту (виявлення проблеми, пояснення причин неефективності попередніх засобів боротьби, переконання в необхідності застосування нових засобів, гарантування позитивного результату); 2) маніпулювання спрощеними поняттями: зберігається протиставлення минуле - сучасне та 3'являється протиставлення сучасне - майбутнє, тепер характер протиставлення можна назвати «чорно-сіро-білим» (минулого року була погана ситуація на дорогах, цього року після впровадження нових засобів боротьби вона стала кращою, але кардинально змінити ситуацію на краще, поставити крапку в боротьбі з порушниками здатен саме цей, найновіший засіб відеоспостереження); 3) процес номінування (тенденційний хабародавець $i$ хабароотримувач); 4) велика кількість порівнянь (тепер - скоро буде; поки щзо - вже незабаром; стало менше порушень; поменшало поранених і загиблих; потрібен суворіший закон).

Позитивне сприйняття нових урядових заходів формується знову за допомогою таких мовних засобів: перебільшення (кардинально покращчтті; об'єктивною може бути лише відеокамера), іронія (лихачі; ювілейний арешт; поєднувати основну роботу 3 «хобi»), стильовий контраст (застосування камер відеоспостереження - i головне ноу-хау; базікання по мобілці за кермом; відмовляються від «відкупного»), використання оцінних сталих сполук (лихачам радять тримати кишені ширше).

У газеті «Криминальная хроника» (№ 2, 2008 р.) у той самий період була надрукована стаття Фальшивок у нас вистачає... або Правила дорожнього руху для всіх однакові, що також відображає боротьбу із правопорушеннями на дорогах. Проте, відповідно до цільових установок видання, основна увага звертається на конкретні факти порушень (зміст статті - вилучення підроблених і недійсних документів - заявлений уже в заголовку та в назві підрубрики: Операція «Документ»), а також підкреслюється закономірність, регулярність виявлення порушень працівниками ДАІ. Прямого протиставлення раніше - тепер, як у газеті «Іменем закону», немає, проте виявляється протиставлення приховане. У загальному контексті тогочасної правоохоронної періодики відбувається навіювання установки: сьогодні панує законність, раніше - кумівство (ярлик кумівство - маніпулювання спрощеними поняттями).

Лейтмотив статті - сьогодні всі рівні перед законом. Про це 
свідчить іï структурування: у заголовку та в кінці тексту повторюється вислів Правила дорожнього руху для всіх однакові, у висновку думка узагальнюється: У правовій державі все має робитися на правовій основі, отже, принципові, рішучі дії правоохоронців - необхідна умова розбудови правової держави.

Сам текст побудований як довірлива розмова із читачем: у вступі 3 метою зацікавлення ставляться запитання (Якими ж підробленими документами намагаються махлювати зараз водії-відчайдухи? На чому намагаються зекономити?); перехід до основної частини, тобто до наведення конкретних фактів, відбувається за допомогою вставної конструкції Скажемо відразу, завдяки чому основний текст сприймається як безпосередня відповідь на поставлені запитання; вставні слова взагалі використовуються протягом усього тексту (словом; як кажуть; скажімо; як відомо); використовується розмовна лексика та фразеологія (водіiвідчайдухи; корочки; підсовують; фальшивки всякого роду $і$ масті; видавити скупу сльозу), а також властиві розмовному стилю неповні речення (І правильно; Ніяк).

Крім структурування тексту, як засіб маніпуляції використовується процес номінування (недійсний або підроблений документ - фальшивка, макулатура), застосовується іронія ( $\epsilon$ y водїв-порушників «хобі»). Своєрідно використана інклюзивна та дистанційна функція займенників: спочатку займенник ми об'єднує автора і читача як членів одного суспільства (фальшивок у нас вистачає), потім, завдяки вживанню займенників другої особи, читач відчуває себе в ролі порушника ( $\mathrm{Ha}$ вашому вітровому склі... звичайна фальшивка, якої вже при першій зустрічі зі співробітниками ДАІ ви неодмінно позбудетесь). Слово неодмінно підсилює ефект попередження: якщо ви порушите закон і цим протиставите себе суспільству, ви обов' язково будете покарані. Після цього водї-порушники (вони) послідовно відмежовуються від «співрозмовників» - автора та читача. Складається враження, що, попередивши вас, автор тепер упевнений, що ви не порушите закон, i після попередження ви із «чужого» стали «своїм». Тільки в кінці статті, у підтексті, вже не для вас, а для нас усіх попередження повторюється, імовірно, для підсилення виховної функції (Хто $і$ які посади не займав би, а Правила дорожнього руху для всіх однакові).

Дослідження маніпулятивного мовного впливу у вітчизняних правоохоронних виданнях дозволяє стверджувати, що ситуація в суспільстві не прикрашається, а роль правоохоронців у боротьбі зі злочинністю не перебільшується. Усі маніпулятивні засоби 
спрямовані на досягнення основних цілей: 1) сформувати думку про ефективність дій правоохоронних органів; 2) застерегти, закликати до обачності та навчити протидіяти злочинцям. Наведені цілі об'єднують переважну більшість статей різного змісту: про боротьбу 3 наркоторгівлею, торгівлею людьми, виробництвом та поширенням порнографії, з шахрайством. Самі злочини при цьому не описуються детально. Це дозволяє стверджувати, що така інформація наводиться не 3 метою привернення уваги до газети, а ризик того, що матеріал може бути використаний як інструкція до злочинних дій, мінімальний. Це відрізняє правоохоронні видання від більшості сучасних вітчизняних 3МI, особливо телебачення.

Характеризувати такий маніпулятивний вплив як недеструктивний дозволяє його орієнтування на позитивні результати. По-перше, це відчуття стабільності та захищеності, дефіцит якого сьогодні гостро відчувається українцями. По-друге, формування позитивного іміджу правоохоронця, повага до захисників правопорядку, що є необхідним у правовому суспільстві. У результаті створення позитивного іміджу правозахисника покращується ставлення до правоохоронних органів; демонструється позитивний приклад для майбутніх правоохоронців, зокрема курсантів; у представників молодшого покоління формується бажання стати правоохоронцями; образ правозахисника-професіонала служить застереженням потенційним порушникам правопорядку.

Дослідження маніпулювання у друкованих виданнях військової та правоохоронної сфер дозволило виявити основні мовні та дискурсивні прийоми, за допомогою яких здійснюється маніпулятивний вплив і які можуть слугувати індикаторами для виявлення маніпуляцій. Регулярність використання певних прийомів залежить не тільки від маніпулятивних цілей, а й від специфіки тієї сфери діяльності, яку обслуговує друковане видання. Наприклад, у регулярному цитуванні керівництва держави та міністерства, в апелюванні до авторитету враховується соціальний контекст, адже військові та правоохоронці звикли керуватися наказами; у постійному протиставленні негативного минулого i позитивного майбутнього враховується прагматичний контекст: показати, що все змінюється на краще. Загалом аналіз військових та правоохоронних ЗМI засвідчив, що в текстах цих видань маніпулятивний мовний вплив не буває деструктивно спрямованим. Деструктивний маніпулятивний вплив реалізується там, де є негативні ідеологічні установки, а військові та 
правоохоронні видання націлені на позитив.

Викладені спостереження дозволяють стверджувати, що маніпулювання в аналізованих виданнях здійснюється в межах кооперативних комунікативних стратегій. Аналіз комунікативних стратегій мовного впливу у військовій та правоохоронній періодиці розглядаємо як перспективу дослідження.

\section{Література}

1. Глинчевский Э. И. Средства речевого воздействия в языке СМИ / Э. И. Глинчевский // Вестник МГУ. Сер 19. Лингвистика и межкультурная коммуникация. - 2005. - № 4. - С. 18-27.

2. Дмитрук О. В. Маніпулятивні прийоми у сучасних 3МІ / О. В. Дмитрук // Мовні і концептуальні картини світу : зб. наук. праць. - К. : КНУ, 2004. - № 10. C. $143-150$.

3. Доценко Е. Л. Психология манипуляции: феномены, механизмы и защита [Электронный ресурс] / Е. Л. Доценко. - СПб. : Речь, 2004. - Режим доступа : http://www.rech.spb.ru.

4. Желтухина М. Р. Тропологическая суггестивность масс-медиального дискурса : о проблеме речевого воздействия тропов в языке СМИ : [монография] / М. Р. Желтухина М. : Ин-т языкознания РАН, 2003. - 656 с.

5. Иссерс О. С. Коммуникативные стратеги и тактики русской речи / О. С. Иссерс. - М. : Издательство ЛКИ, 2008. - 288 с.

6. Кара-Мурза С. Г. Власть манипуляции / С. Г. Кара-Мурза. - М. : Академический проект, 2007. - $380 \mathrm{c}$.

7. Кудрявцева Л. О. Сучасні аспекти дослідження мас-медійного дискурсу : експресія - вплив - маніпуляція / Л. О. Кудрявцева, Л. П. Дядечко, О. М. Дорофєєва // Мовознавство. - 2005. - № 1. - С. 58-66.

8. Левин Р. В. Механизмы манипуляции. Защита от чужого влияния / Р. В. Левин. - К. : Диалектика, 2007. - 429 с.

9. Пелепейченко Л. М. Специфіка мовного впливу на читача в мас-медійному просторі військової та правоохоронної сфер України / Л.М.Пелепейченко, В. В. Посмітна // Філологічні науки : зб. наук. праць. - Суми : СумДПУ імені А. С. Макаренка, 2008. - С. 104-112.

10. Почепцов Г. Г. Паблик рилейшнз, или Как успешно управлять общественным мнением / Г. Г. Почепцов. - М. : Центр, 2004. - 336 с.

11. Різун В. В. Теорія масової комунікації : [підруч. для студ. галузі 0303 «журналістика та інформація»] / В. В. Різун. - К. : ВЦ «Просвіта», 2008. - 260 с.

12. Седов К. Ф. О манипуляции и актуализации в речевом воздействии / К. Ф. Седов // Проблемы речевой коммуникации : межвуз. сб. науч. тр. - Саратов : Изд-во Сарат. ун-та, 2003. - Вып. 2. - С. 20-27.

13. Сугестивні технології маніпулятивного впливу : [навч. посіб.] / [В. М. Петрик, М. М. Присяжнюк, Л.Ф. Компанцева та ін.] ; за заг. ред. Є. Д. Скулиша. - [2-ге вид.]. К. : 3АТ «ВІПОЛ», 2011. $-248 \mathrm{c}$.

14. Шиллер Г. Манипуляторы сознанием / Г. Шиллер. - М. : Мысль, 1980. - 326 с. Стаття надійшла до редакції 31.08.2012 p. 